\title{
NMR resonance assignments of the pathogenesis-related peach allergen Pru p 1.0101
}

\author{
Sebastian Führer ${ }^{1} \cdot$ Simone Trimmel $^{1} \cdot$ Kathrin Breuker $^{1} \cdot$ Martin Tollinger $^{1} \mathbb{C}$
}

Received: 30 November 2018 / Accepted: 6 December 2018 / Published online: 12 December 2018

(c) The Author(s) 2018

\begin{abstract}
In Europe, Northern America, and China a large number of individuals are suffering from peach (Prunus persica) allergy caused by the protein Pru p 1. Immunologic reactions against this $17.5 \mathrm{kDa}$ protein result from initial sensitization to the birch (Betula verrucosa) pollen allergen Bet $\mathrm{v} 1$ and subsequent immunologic cross-reactivity of Bet $\mathrm{v} 1$ specific antibodies. Allergic symptoms typically include severe itching, scratching of the throat, and rhino conjunctivitis. So far, experimental structural data for the peach allergen Pru p 1 are not available. In a first step towards the elucidation of the structure of this protein we assigned backbone and side chain ${ }^{1} \mathrm{H},{ }^{13} \mathrm{C}$, and ${ }^{15} \mathrm{~N}$ chemical shifts of the naturally occurring isoform Pru $\mathrm{p} 1.0101$ by solution NMR spectroscopy. Our chemical shift data indicate that this protein fold consists of seven $\beta$-strands separated by two short $\alpha$-helices and a long $\mathrm{C}$-terminal $\alpha$-helix, which is in accordance with the reported crystal structure of Bet $\mathrm{v} 1$. Our data provide the basis for determining the three-dimensional solution structure of this protein and to characterize its immunologic cross-reactivity on a structural basis.
\end{abstract}

Keywords NMR resonance assignment $\cdot$ TALOS + prediction $\cdot$ PR-10 protein $\cdot$ Cross-reactivity $\cdot$ Allergen

\section{Biological context}

In the northern hemisphere, individuals who are sensitized to birch pollen show IgE serum reactivity against the protein Bet v 1, the major birch pollen allergen, in about $90 \%$ of all cases (Ipsen and Lowenstein 1983; Moverare et al. 2002). Patients suffering from birch pollinosis can additionally develop allergies to fruits and nuts due to immunological cross-reactivity of Bet $\mathrm{v} 1$ specific antibodies to proteins that are present in these kinds of food. Consumption of fruits and nuts then triggers oral allergic syndromes (OAS) in many cases, including swelling and itching of the tongue, throat and lips (Mari et al. 2005). Indeed, 30-50\% of birch pollen allergic individuals show allergic reactions after consuming peaches (Geroldinger-Simic et al. 2011; Pastorello et al. 1994), a prevalence that is only exceeded by allergic reactions to apples and hazelnuts (Geroldinger-Simic et al. 2011).

Martin Tollinger

martin.tollinger@uibk.ac.at

1 Institute of Organic Chemistry and Center for Molecular Biosciences Innsbruck (CMBI), University of Innsbruck, Innrain 80/82, 6020 Innsbruck, Austria
Immunological cross-reactivity to birch pollen is related to the protein Pru p 1 that is present in peaches (Mills and Shewry 2004). Pathogens or stress can induce the expression of Pru p 1, which is believed to be involved in the general plant defense mechanisms (Fernandes et al. 2013). Pru p 1 is distinct from another allergen in peach, Pru p 3, a nonspecific lipid transfer protein that provokes severe allergic reactions typically in the Mediterranean population (Fernandez-Rivas et al. 2003; Pastorello et al. 1999) and which is present in peaches in higher concentrations (Ahrazem et al. 2007). Like its homolog Bet v 1, Pru p 1 belongs to the group 10 of pathogenesis-related (PR) proteins, which have a size of about $17 \mathrm{kDa}$ and consist of about 160 amino acid residues. The PR-10-fold comprises a seven-stranded antiparallel $\beta$-sheet $(\beta 1-\beta 7)$ that is covered by a long C-terminal $\alpha$-helix $(\alpha 3)$ and two short $\alpha$-helices $(\alpha 1, \alpha 2)$ interrupting the $\beta$-sheet between strands $\beta 1$ and the consecutive strands $\beta 2-\beta 7$. Pru $p 1$ is easily degraded and heat labile (Asero et al. 2001), which is in accordance with other PR-10 proteins. Three naturally occurring isoforms of Pru $p 1$ have been identified in the 'Early Gold' peach cultivar (Chen et al. 2008) and their efficacies of IgE-binding have been studied (Gao et al. 2016). The Pru p 1.0101 (DQ251187) and Pru p 1.0201 (KM350692) isoforms are present in the peach fruit 
and the Pru p 1.0301 (KM350693) allergen is present in the peach pollen and the leaves of the peach tree (Gao et al. 2016). Experimental structural data for Pru p 1 isoforms are not available to date and NMR resonance assignments have not been published. Here we present the solution NMR backbone and side-chain assignment of the recombinantly expressed isoform Pru p 1.0101. This particular isoform shares sequence identity of $59 \%$ with the sensitizing allergen Bet v 1.0101 (Gajhede et al. 1996). Sequence identity to the most prominent cross-reactive allergen in food, the major allergen from apple (Malus domestica) Mal d 1.0101, is considerably higher (82\%) (Ahammer et al. 2017, 2016).

\section{Methods and experiments}

\section{Sample preparation}

The codon-optimized DNA of Pru p 1.0101 (GenBank nucleotide code DQ251187 and protein code ABB78006) was cloned into the expression vector pET28b (+) by the restriction enzymes NcoI and XhoI. Plasmid transformation was carried out in the E. coli strain BL21(DE3) Star (Invitrogen). A starter culture (100 mL) of Luria Bertani (LB) medium containing $25 \mu \mathrm{g} / \mathrm{mL}$ kanamycin was prepared by inoculation with one single bacterial colony and incubated at $37^{\circ} \mathrm{C}$ and $220 \mathrm{rpm}$ overnight. The cells of $50 \mathrm{~mL}$ of the starter culture were collected by centrifugation $(2000 \times g)$ and resuspended in $1 \mathrm{~L}$ of M9 minimal medium supplemented with $25 \mu \mathrm{g} / \mathrm{mL}$ kanamycin and enriched with ${ }^{13} \mathrm{C}_{6}$-D-glucose and/or ${ }^{15} \mathrm{NH}_{4} \mathrm{Cl}$ (both Cambridge Isotope Laboratories). Incubation of the culture was carried out at $37{ }^{\circ} \mathrm{C}$ and $220 \mathrm{rpm}$ until the cell density reached about 0.5 and induction of protein expression was induced by IPTG (isopropyl- $\beta$-D-1-thiogalactopyranosid, $1 \mathrm{mM}$ ). Incubation was performed for $3 \mathrm{~h}$ at $37{ }^{\circ} \mathrm{C}$ and afterwards the cells were harvested by centrifugation at $3440 \times g$ and $4{ }^{\circ} \mathrm{C}$ for $30 \mathrm{~min}$. The cell pellets were resuspended in $25 \mathrm{mM}$ imidazole, $0.1 \%$ Triton $\mathrm{X}-100$, and $0.5 \mathrm{M}$ urea. The cell suspension was shock-frozen in liquid nitrogen and stored at $-80{ }^{\circ} \mathrm{C}$ until usage. For Pru p 1 purification, the frozen cells were thawed and pre-treated with lysozyme $(10 \mu \mathrm{g} / \mathrm{mL})$ for $1 \mathrm{~h}$ on ice. Subsequently, DNAse I $(1 \mu \mathrm{g} / \mathrm{mL})$ was added and cells were lysed with a French Press. The lysate was centrifuged at $15,000 \times \mathrm{g}$ and $4{ }^{\circ} \mathrm{C}$ for $40 \mathrm{~min}$ and loaded onto an anion exchange column (Resource Q $6 \mathrm{ml}$, GE Healthcare). Pru p 1.0101 was eluted with a sodium chloride gradient over $30 \mathrm{~mL}$ from 0 to $50 \%$ in $25 \mathrm{mM}$ TrisHCl buffer ( $\mathrm{pH} \mathrm{7.5)} \mathrm{at}$ a flow rate of $2 \mathrm{~mL} / \mathrm{min}$. Fractions containing Pru p 1.0101 were collected and concentrated to $1-2 \mathrm{~mL}$ by centrifugation (Amicon Ultra $3 \mathrm{kDa}$ MWCO, Merck Millipore). In the final step, the protein was loaded onto a size exclusion column (HiLoad 16/600 Superdex 75 prep grade, GE Healthcare) and eluted with $10 \mathrm{mM}$ sodium phosphate buffer $(\mathrm{pH}$ 6.9) at a flow rate of $1 \mathrm{~mL} / \mathrm{min}$. Fractions containing Pru p 1.0101 were pooled and concentrated. For NMR spectroscopy, samples were supplemented with $10 \% \mathrm{D}_{2} \mathrm{O}(\mathrm{v} / \mathrm{v})$, yielding concentrations of $0.5 \mathrm{mM}$ for ${ }^{15} \mathrm{~N}$ labeled and ${ }^{15} \mathrm{~N} /{ }^{13} \mathrm{C}$ labeled Pru p 1.0101.

Expression and purification steps of Pru p 1.0101 were monitored by SDS-PAGE gel electrophoresis using 15\% gels. The purified protein was analyzed by mass spectrometry using a $7 \mathrm{~T}$ Fourier-transform ion cyclotron resonance mass spectrometer (FT-ICR MS; Apex Ultra 70, Bruker Daltonics) with an electrospray ionization (ESI) source. The degree of isotope labeling for ${ }^{15} \mathrm{~N}$ and ${ }^{15} \mathrm{~N} /{ }^{13} \mathrm{C}$ labeling was determined as $99.5 \pm 0.1 \%$ and $98.8 \pm 0.1 \%$, respectively. In addition, the mass spectrometry data showed that in $97 \%$ of Pru p 1.0101 the N-terminal methionine was cleaved off.

\section{NMR spectroscopy}

All NMR spectra were recorded at $25{ }^{\circ} \mathrm{C}$ on a $500 \mathrm{MHz}$ Agilent DirectDrive 2 spectrometer equipped with a room temperature probe. A two-dimensional ${ }^{1} \mathrm{H}-{ }^{15} \mathrm{~N}-\mathrm{HSQC}$ and three-dimensional $\mathrm{HNCACB}, \mathrm{CBCA}(\mathrm{CO}) \mathrm{NH}, \mathrm{HNCO}$, and $\mathrm{HN}(\mathrm{CA}) \mathrm{CO}$ experiments were performed for backbone resonance assignments. Side-chain assignments were obtained by using ${ }^{1} \mathrm{H}-{ }^{13} \mathrm{C}-\mathrm{HSQC}$ and three-dimensional $\mathrm{H}(\mathrm{CCO}) \mathrm{NH}-$ TOCSY, (H)CC(CO)NH-TOCSY, ${ }^{1} \mathrm{H}_{-}{ }^{15} \mathrm{~N}-\mathrm{TOCSY}-\mathrm{HSQC}$, ${ }^{1} \mathrm{H}_{-}{ }^{15} \mathrm{~N}-\mathrm{NOESY}-\mathrm{HSQC}$, and ${ }^{1} \mathrm{H}_{-}{ }^{13} \mathrm{C}-\mathrm{NOESY}-\mathrm{HSQC}$ experiments. Processing of the collected data was done with NMRPipe (Delaglio et al. 1995) and resonance assignment was performed using CcpNMR (Vranken et al. 2005) software.

\section{Assignments and data deposition}

In the ${ }^{1} \mathrm{H}^{15} \mathrm{~N}-\mathrm{HSQC}$ spectrum of Pru p 1.0101 (Fig. 1) we achieved an assignment for 142 of 151 non-proline residues corresponding to $94.0 \%$ completeness. Assignments of $\mathrm{C}^{\alpha}$ and $\mathrm{C}^{\beta}$ resonances are $95.6 \%$ and $95.8 \%$ complete, respectively, while backbone $\mathrm{C}^{\prime}$ assignments are $94.3 \%$ complete. Side-chain $\mathrm{C}^{\gamma}, \mathrm{C}^{\delta}$, and $\mathrm{C}^{\varepsilon}$ were assigned to $69.0 \%$, $57.8 \%$, and $45.0 \%$ completeness, respectively. In addition, 93.7\% of $\mathrm{H}^{\alpha}$ and $93.6 \%$ of $\mathrm{H}^{\beta}$ resonances along with $84.8 \%$, $71.3 \%$, and $61.9 \%$ of side-chain $\mathrm{H}^{\gamma}, \mathrm{H}^{\delta}$, and $\mathrm{H}^{\varepsilon}$ resonances, respectively, were assigned. Full assignments of the sidechain amides $\left({ }^{1} \mathrm{H}\right.$ and $\left.{ }^{15} \mathrm{~N}\right)$ of all five asparagine and two glutamine residues, along with the side-chain $\mathrm{H}^{\varepsilon} / \mathrm{N}^{\varepsilon}$ of the single arginine residue at position 17 were obtained. The chemical shift data of Pru p 1.0101 have been deposited at the Biological Magnetic Resonance Data Bank (http://www. bmrb.wisc.edu) with the BMRB accession number 27687.

The amino acid sequence of Pru p 1.0101 was verified by MS/MS (Fig. 2a), showing 96\% sequence coverage. Secondary structure elements of Pru p 1.0101 were 
Fig. $1500 \mathrm{MHz}{ }^{1} \mathrm{H}-{ }^{15} \mathrm{~N}-\mathrm{HSQC}$ spectrum of Pru p 1.0101 $(0.5 \mathrm{mM})$ in $20 \mathrm{mM}$ sodium phosphate (pH 6.9), supplemented with $10 \% \mathrm{D}_{2} \mathrm{O}, 25^{\circ} \mathrm{C}$. Assigned residues are indicated using single letter codes and horizontal lines indicate asparagine and glutamine $\mathrm{NH}_{2}$ side-chain resonances. The signal labeled by an asterisk indicates the position of the residue below the intensity cutoff. Resonance assignments are available online at the BMRB repository (Accession Number 27687)

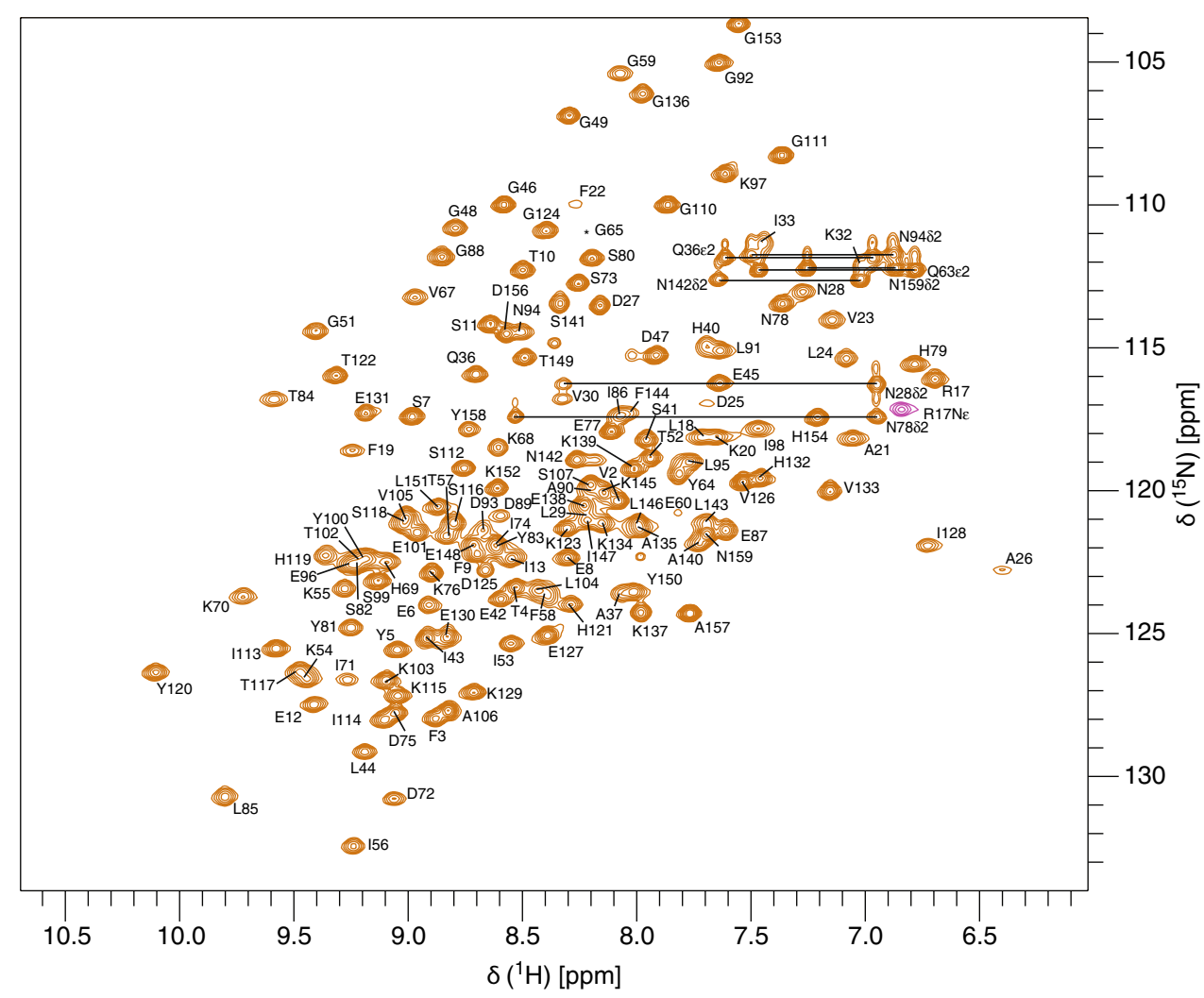

a

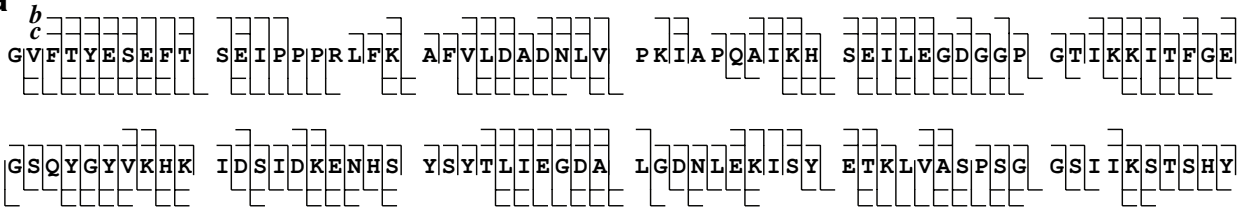
甚

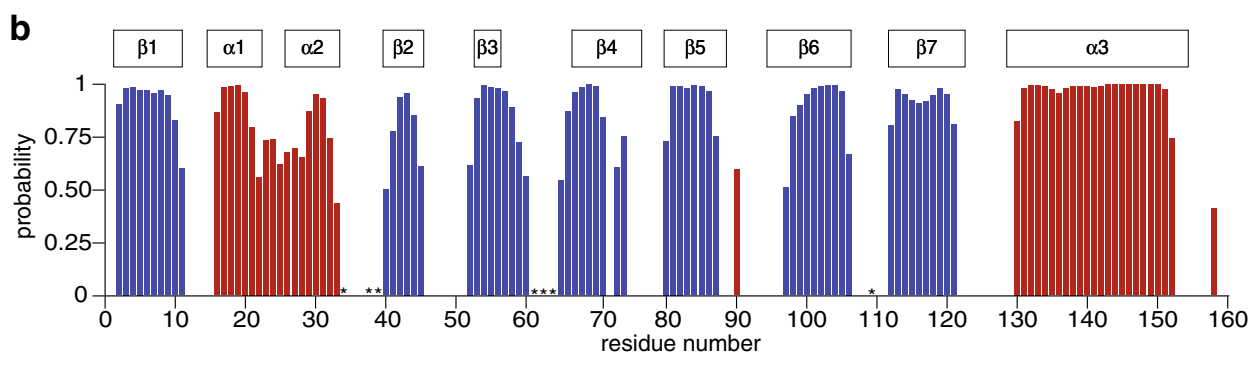

Fig. 2 Primary and secondary structure of Pru p 1.0101 a MS/MS fragment map for the 159-residue protein Pru p 1.0101 (measured mass for most abundant isotopic signal: $17515.97 \mathrm{Da}$, calculated: $17515.99 \mathrm{Da}$ ) illustrating $96 \%$ sequence coverage; $c, z^{\bullet}$ and $b, y$ fragments were produced by electron capture dissociation (ECD) and collisionally activated dissociation (CAD), respectively. b TALOS+ pre-

obtained by the TALOS+ prediction software (Shen et al. 2009) using the $\mathrm{H}^{\mathrm{N}}, \mathrm{N}, \mathrm{C}^{\prime}, \mathrm{C}^{\alpha}$, and $\mathrm{C}^{\beta}$ backbone chemical diction of Pru p 1.0101 secondary structure elements based on backbone $\mathrm{H}^{\mathrm{N}}, \mathrm{N}, \mathrm{C}^{\prime}, \mathrm{C}^{\alpha}$, and $\mathrm{C}^{\beta}$ chemical shifts. The secondary structure probabilities (red, $\alpha$-helices; blue, $\beta$-strands) are plotted against the residue numbers. Residues for which backbone amide $\mathrm{NH}$ resonance assignments are not available are indicated by asterisks. Secondary structure elements of Bet v 1.0101 (PDB: 4A88) are indicated

shifts as input (Fig. 2b). Our data shows that this protein comprises seven $\beta$-strands ( $\beta 1-\beta 7)$, two short $\alpha$-helices $(\alpha 1$ 
and $\alpha 2$ ) and a long C-terminal $\alpha$-helix ( $\alpha 3)$, which is consistent with the PR-10 fold found in crystallographic and NMR spectroscopic investigations of Bet v 1.0101 and Mal d 1.0101, respectively (PDB: 4A88 and 5MMU). In addition, the segment between $\beta 5$ and $\beta 6$ and the $C$-terminal region after $\alpha 3$ appear to have a moderate propensity for $\alpha$-helical structure. The NMR resonance assignment of Pru p 1.0101 obtained here provides the basis for determining the threedimensional solution structure of this important protein in the future.

Acknowledgements Open access funding was provided by the Austrian Science Fund (FWF). This work was supported by the Austrian Science Fund FWF (P26849 to M.T., P27347 to K.B.). We thank Dr. Thomas Müller and Christina Meisenbichler for mass spectrometry experiments.

Open Access This article is distributed under the terms of the Creative Commons Attribution 4.0 International License (http://creativeco mmons.org/licenses/by/4.0/), which permits unrestricted use, distribution, and reproduction in any medium, provided you give appropriate credit to the original author(s) and the source, provide a link to the Creative Commons license, and indicate if changes were made.

\section{References}

Ahammer L, Grutsch S, Tollinger M (2016) NMR resonance assignments of the major apple allergen Mal d 1. Biomol NMR Assign 10:287-290. https://doi.org/10.1007/s12104-016-9685-8

Ahammer L, Grutsch S, Kamenik AS, Liedl KR, Tollinger M (2017) Structure of the major apple allergen Mal d 1. J Agric Food Chem 65:1606-1612. https://doi.org/10.1021/acs.jafc.6b05752

Ahrazem $\mathrm{O}$ et al (2007) Assessing allergen levels in peach and nectarine cultivars. Ann Allergy Asthma Immunol 99:42-47. https://doi. org/10.1016/S1081-1206(10)60619-9

Asero R, Mistrello G, Roncarolo D, Casarini M, Falagiani P (2001) Allergy to nonspecific lipid transfer proteins in Rosaceae: a comparative study of different in vivo diagnostic methods. Ann Allergy Asthma Immunol 87:68-71. https://doi.org/10.1016/ S1081-1206(10)62326-5

Chen L et al (2008) Genomic characterization of putative allergen genes in peach/almond and their synteny with apple. BMC Genom 9:543. https://doi.org/10.1186/1471-2164-9-543
Delaglio F, Grzesiek S, Vuister GW, Zhu G, Pfeifer J, Bax A (1995) NMRPipe: a multidimensional spectral processing system based on UNIX pipes. J Biomol NMR 6:277-293. https://doi. org/10.1007/BF00197809

Fernandes H, Michalska K, Sikorski M, Jaskolski M (2013) Structural and functional aspects of PR-10 proteins. FEBS J 280:1169-1199. https://doi.org/10.1111/febs.12114

Fernandez-Rivas M et al (2003) Clinically relevant peach allergy is related to peach lipid transfer protein, Pru p 3, in the Spanish population. J Allergy Clin Immunol 112:789-795. https://doi. org/10.1016/S0091

Gajhede M et al (1996) X-ray and NMR structure of Bet v 1, the origin of birch pollen allergy. Nat Struct Biol 3:1040-1045

Gao ZS et al (2016) IgE-binding potencies of three peach Pru $p 1$ isoforms Mol. Nutr Food Res 60:2457-2466. https://doi.org/10.1002/ mnfr.201500798

Geroldinger-Simic M et al (2011) Birch pollen-related food allergy: clinical aspects and the role of allergen-specific IgE and IgG4 antibodies. J Allergy Clin Immunol 127:616-622 e611. https:// doi.org/10.1016/j.jaci.2010.10.027

Ipsen H, Lowenstein H (1983) Isolation and immunochemical characterization of the major allergen of birch pollen (Betula verrucosa). J Allergy Clin Immunol 72:150-159

Mari A, Ballmer-Weber BK, Vieths S (2005) The oral allergy syndrome: improved diagnostic and treatment methods. Curr Opin Allergy Clin Immunol 5:267-273

Mills ENC, Shewry PR (2004) Plant food allergens. Blackwell Science, Oxford; Malden

Moverare R et al (2002) Different IgE reactivity profiles in birch pollen-sensitive patients from six European populations revealed by recombinant allergens: an imprint of local sensitization. Int Arch Allergy Immunol 128:325-335

Pastorello EA et al (1994) Allergenic cross-reactivity among peach, apricot, plum, and cherry in patients with oral allergy syndrome: an in vivo and in vitro study. J Allergy Clin Immunol 94:699-707

Pastorello EA et al (1999) The major allergen of peach (Prunus persica) is a lipid transfer protein. J Allergy Clin Immunol 103:520-526

Shen Y, Delaglio F, Cornilescu G, Bax A (2009) TALOS+: a hybrid method for predicting protein backbone torsion angles from NMR chemical shifts. J Biomol NMR 44:213-223. https://doi. org/10.1007/s10858-009-9333-z

Vranken WF et al (2005) The CCPN data model for NMR spectroscopy: development of a. software pipeline Proteins 59:687-696. https://doi.org/10.1002/prot.20449 